\title{
Nasionale dienspligveterane se soeke na afsluiting (closure): 'n Pastorale sorg uitdaging
}

\begin{tabular}{|c|c|}
\hline \multicolumn{2}{|c|}{$\begin{array}{l}\text { Authors: } \\
\text { Roelf Schoeman }{ }^{1} \\
\text { Yolanda Dreyer }^{1}\end{array}$} \\
\hline \multicolumn{2}{|c|}{$\begin{array}{l}\text { Affiliations: } \\
{ }^{1} \text { Department of Practical } \\
\text { Theology, Faculty of Theology } \\
\text { and Religion, University of } \\
\text { Pretoria, Pretoria, South Africa }\end{array}$} \\
\hline \multicolumn{2}{|c|}{$\begin{array}{l}\text { Research Project Registration: } \\
\text { Project Leader: Y. Dreyer } \\
\text { Project Number: } 2546930\end{array}$} \\
\hline \multicolumn{2}{|c|}{$\begin{array}{l}\text { Description: } \\
\text { This research is part of the } \\
\text { project, 'Gender Studies and } \\
\text { Practical Theology Theory } \\
\text { Formation', directed by } \\
\text { Prof. Dr Yolanda Dreyer, } \\
\text { Department of Practical } \\
\text { Theology, Faculty of Theology } \\
\text { and Religion, University } \\
\text { of Pretoria. }\end{array}$} \\
\hline \multicolumn{2}{|c|}{$\begin{array}{l}\text { Corresponding author: } \\
\text { Yolanda Dreyer, } \\
\text { yolanda.dreyer@up.ac.za }\end{array}$} \\
\hline \multicolumn{2}{|c|}{$\begin{array}{l}\text { Dates: } \\
\text { Received: } 26 \text { Feb. } 2019 \\
\text { Accepted: } 15 \text { July } 2019 \\
\text { Published: } 29 \text { Nov. } 2019\end{array}$} \\
\hline \multicolumn{2}{|c|}{$\begin{array}{l}\text { How to cite this article: } \\
\text { Schoeman, R. \& } \\
\text { Dreyer, Y., 2019, 'Nasionale } \\
\text { dienspligveterane se soeke } \\
\text { na afsluiting (closure): 'n } \\
\text { Pastorale sorg uitdaging', } \\
\text { HTS Teologiese Studies/ } \\
\text { Theological Studies 75(4), } \\
\text { a5441. https://doi.org/ } \\
\text { 10.4102/hts.v75i4.5441 }\end{array}$} \\
\hline \multicolumn{2}{|c|}{$\begin{array}{l}\text { Copyright: } \\
\text { C 2019. The Authors } \\
\text { Licensee: AOSIS. This } \\
\text { is licensed under the } \\
\text { Creative Commons } \\
\text { Attribution License. }\end{array}$} \\
\hline \multicolumn{2}{|l|}{ Read online: } \\
\hline 口'top & $\begin{array}{l}\text { Scan this } Q R \\
\text { code with your } \\
\text { smart phone or } \\
\text { mobile device } \\
\text { to read online. }\end{array}$ \\
\hline
\end{tabular}

National conscripts and their quest for closure: A Pastoral challenge. During the apartheid era, young white men were conscripted for military service in the South African Defence Force. After the demise of apartheid, these military veterans became part of the transformation process in the country. They were often not prepared for the emotional and psychological impact of the political, economic and social changes. Many of them found and still find it difficult to take their place among the citizenry of the country. The post-apartheid government provided no support for them to reintegrate into the community or to process the often long-lasting effects of war related trauma and moral injury. For many, this resulted in a lack of healing and closure on a psychological, moral and spiritual level. This article aims to contribute from a pastoral care perspective to the process of healing, closure and reintegration of this specific group. A holistic narrative approach integrates the contextual approach of Charles Gerkin, the philosophical counselling of Daniel Louw and the insights of Neil Anderson with regard to the connection between spirituality and identity. A contextual approach promotes a deeper understanding of the veterans and their needs in the context of their local communities, including faith communities. In these local communities, resources are available and should be utilised. Such a constructive engagement between veterans, local communities and faith communities can contribute to healthier individuals, families and communities as well as to a healthier society. Guidelines for pastoral support of these veterans that can contribute to their social and personal transformation and process of psychological closure are proposed.

Keywords: South African National Conscription Veterans; War-Related Trauma; Moral Injury; Closure; Pastoral Care.

\section{Inleiding}

Hierdie artikel het ten doel om vanuit' $n$ pastorale perspektief aan te toon hoe 'n bydrae gemaak kan word ten opsigte van sommige voormalige nasionale dienspligveterane (NDP's) se afsluitingsproses en hulle herintegrasie in die gemeenskap. Verskeie faktore het daartoe bygedra dat sommige voormalige nasionale NDP's 'n lewenshouding ontwikkel het wat negatief op hulle lewens- en persoonlike groeimoontlikhede inwerk, en daardeur word heling en afsluiting (closure) verhinder. Bestaande studies oor pastorale sorg met oorlogsveterane en transformasieprosesse in ander dele van die wêreld soos die van Snape en Henshaw (2017) in Brittanje en Husted (2008), Fuson (2013), Moon (2016a; 2016b), Yan (2016), David (2017) en Doehring (2018) in die VSA het tot waardevolle insigte bygedra. Wat die Suid-Afrikaanse konteks betref, is daar egter unieke uitdagings.

In Suid-Afrika bestaan die milieu van NDP's uit die voortgaande transformasie van die samelewing. Vir hierdie militêre veterane was die uitdaging nie net om weer tuis te raak en aan te pas in die samelewing na hulle terugkeer van die grensoorlog nie. Hulle uitdaging is verder om saam met die res van die land se bevolking in 'n proses van voortdurende transformasie hulle nuwe plek in 'n nuwe samelewing te vind. Vir baie NDP's het dit beteken dat die proses van hulle verwerking van die oorlog, hulle heraanpassing in die samelewing en afsluiting nie goed gevorder het nie. Voortdurende transformasie in die samelewing en werkplek sowel as veranderings wat tot verliese vir voormalige NDP's gelei het of kan lei, skep onsekerheid oor die toekoms. Wanneer individue of gemeenskappe voortdurend bedreig voel en beduidende verliese in die gesig staar, kan dit negatiewe stres meebring wat negatief op hulle psigiese welsyn kan inwerk.

Nou, teen die einde van die tweede dekade van die een-en-twintigste eeu, begin baie voormalige NDP's aftree-ouderdom bereik. 'n Algemene tendens word in die literatuur aangedui dat oorlogsveterane van die Eerste en Tweede Wêreldoorlog, en veral van die VSA/Viëtnam-oorlog,

Note: This article represents reworked aspects of the PhD-thesis of Roelf Schoeman, completed under the supervision of Prof. Dr Yolanda Dreyer, Department of Practical Theology, Faculty of Theology and Religion, University of Pretoria. 
dikwels eers ná aftrede begin om werklik die traumatiese ervarings wat hulle in die oorlog meegemaak het, intens te beleef (kyk Barman \& Detweiler 2014; Davison et al. 2006:109 110; Horesh et al. 2011; Langer 2011:53; Port et al. 2001). Dit is dan wanneer hulle begin soek na die sin en betekenis van wat hulle ervaar het in die oorloë waarby hulle betrokke was.

Ron Langer (2011) dui aan hoe ander verliese soos die dood van vriende, kinders wat onafhanklik word en egskeiding die sneller is wat Post-Traumatiese Stresversteuring (PTSV) kan teweegbring. Hy (Langer 2011:54) stel dit soos volg: 'A life without meaning leaves plenty of room for PTSD - as well as other psychiatric disorders, such as depression, anxiety, and substance abuse - to fill.' 'n Negatiewe lewenshouding kan destruktiewe gevolge vir mense se lewens sowel as 'n nadelige uitwerking op hulle soeke na sin, betekenis en afsluiting na aftrede hê. Hierdie artikel het ten doel om aan te toon hoe 'n bydrae gemaak kan word ten opsigte van hierdie spesifieke groep se afsluitingsproses.

'n Holistiese benadering word in hierdie artikel gevolg met die klem op 'n narratiewe benadering, die kontekstuele benadering tot pastorale sorg van Charles Gerkin (1997), die filosofiese berading (philosophical counselling) van Daniel Louw (1999; 2005; 2011; 2012; 2015) en die insigte van Neil Anderson et al (2000).

\section{Die probleemsituasie}

F.W. de Klerk, die voormalige staatspresident van die Republiek van Suid-Afrika, se aankondiging op 2 Februarie 1990 dat Nelson Mandela vrygelaat gaan word en dat die regering met die voormalige bevrydingsbewegings gaan onderhandel, het tot die einde van die gewapende stryd van 30 jaar gelei. Die oorgangstydperk voor die algemene verkiesing in 1994 is deur politieke onstabiliteit gekenmerk. $\mathrm{Na}$ die verkiesing het bestendigheid gevolg wat in ' $\mathrm{n}$ groot mate aan die transformasie in die veiligheidsmagte voor en $n a$ die verkiesing toegeskryf kan word.

Hoewel die voormalige dienspligtiges voor die verkiesing in 1994 'n beduidende bydrae tot stabiliteit in die land gelewer het, het hulle oor die algemeen geen erkenning daarvoor ontvang nie. Hulle is deur die destydse Suid-Afrikaanse Weermag (SAW) onder die indruk gebring dat die weermag a-polities was en dat die binneland gestabiliseer moes word om ruimte vir 'n vrye en regverdige verkiesing te skep (kyk Geldenhuys 1993:243; Malan 2006:372-373). Soos met die ander vryheidsoorloë in Suider-Afrika, is die status en term militêre veteraan in die vryheidstryd gewortel (kyk Heinecken \& Bwalya 2013:34). Na 1994 het politieke leiers in Suid-Afrika egter van die standpunt uitgegaan dat voormalige dienspligtiges nooit volwaardige lede van die SAW was nie en dus nie as 'militêre veterane' vir regeringsondersteuning kwalifiseer nie. In 2011 het die Wet op Militêre Veterane (Republic of South Africa 2011) vir die eerste keer amptelike die status van 'militêre veterane' aan voormalige dienspligtiges gegee.

Baie van hierdie militêre veterane is steeds op soek na afsluiting en na die sin en betekenis van oorlogsverwante ervarings, asook die huidige politieke verwikkelinge. 'n Aantal faktore bied besondere uitdagings aan veterane. Sedert 1994 is kulturele fragmentasie 'n kenmerk van die soeke na 'n nuwe Suid-Afrikaanse identiteit. Baie mense is ontnugter omdat die regering nie kon voldoen aan verwagtings wat politici voor 1994 geskep het nie. Menige oorlogsveteraan se lewe word bemoeilik deur PTSV en die feit dat hierdie versteuring nie altyd gediagnoseer en effektief behandel is nie. Hieronder ly nie net die veterane self nie, maar ook hulle families.

\section{Holistiese ondersteuning}

Dienspligtiges en NDP's het voor 1994 goeie ondersteuning van hulle gemeenskappe en die voormalige regering gekry. Hulle was nie voorbereid op die emosionele en psigiese effek van die omvattende politieke, ekonomiese en maatskaplike verandering na 1990 nie. Veral na 1994 was dit 'n groot uitdaging vir NDP's om in 'n land waar omvangryke politieke, ekonomiese en sosiale veranderinge plaasvind en veral waar die wit Afrikaanssprekende gemeenskap hulle vorige staanplek verloor het, aan te pas. Die verhoudingsnetwerke in Afrikaanssprekende gemeenskappe is sedert 1994 onder druk. Die hele Afrikaanssprekende gemeenskap en veral die NDP's is gekonfronteer met 'n verskeidenheid vorme van verlies wat verwerk moes word. Daar was ook nuwe uitdagings wat deurlopend hanteer moes word. Tydens politieke verandering ervaar individue en gemeenskappe 'n verskeidenheid van verliese. Oor ingrypende verlies moet getreur word om tot gesonde psigiese afsluiting te kom wat die grondslag vorm vir die opbou van 'n konstruktiewe lewe vorentoe. Die effek van verlies is gewoonlik erger en die treurproses duur langer as wat die meeste mense besef (kyk Boshoff 2011; Hamman 2005:46-60). Dit beteken dat die proses dikwels nie die nodige aandag ontvang nie.

Herintegrasie na konflik is 'n komplekse en langtermynproses waarin veterane en hulle families ondersteun word met die oog daarop dat die veterane weer polities, ekonomies en maatskaplik in hulle gemeenskappe en in die samelewing kan aanpas en geïntegreer kan word. Die doel is dat hulle weer deel van politieke besluitnemingsprosesse word, ekonomies onafhanklik kan funksioneer en 'n integrerende deel van hulle onderskeie gemeenskappe, insluitende geloofsgemeenskappe, kan vorm.

Ondersteuning is nodig wanneer hulle voor die uitdaging te staan kom om hulle gesindheid en verwagtings aan te pas by die realiteite van die omgewing waarin in hulle hulleself bevind. Hulle psigiese take is om oorlogverwante trauma te verwerk en hulle lewens sodanig aan te pas dat hulle gesonde en produktiewe lede van die gemeenskap kan wees (kyk Dzinesa 2008:5).

Voormalige dienspligtiges was tydens hulle dienspligtyd die swye opgelê. Nou het hulle egter die reg om te praat en hulle verhale te vertel. Literatuur op hierdie gebied het toegeneem. Die ervarings van voormalige dienspligtiges word ook nou 
in die sosiale media vertel. Uit hierdie verhale blyk dit dat die behoefte bestaan om hulle narratiewe te vertel en dat hulle ervarings gehoor word. Jaarlikse herdenkingsdae, seremoniële byeenkomste, rituele en die vertel van verhale vorm reeds deel van veterane se lewens.

Die narratiewe terapeutiese benadering waarvolgens die vertel van lewens- of traumaverhale mense daartoe kan bring om betekenis, perspektief en genesing te vind (kyk Louw 1999:23-24), is 'n nuttige strategie vir pastorale interaksie met hierdie spesifieke groep. Die narratiewe perspektief het mettertyd ook 'n ryk bron van teologiese en praktiesteologiese - veral in die pastoraat - refleksie geword (kyk Ganzevoort 2012:218; Louw 1999:23-24). As 'n effektiewe terapeutiese benadering kan die vertel van individuele narratiewe die sleutel tot verstaan en verandering word (kyk Brunsdon \& Lotter 2011:3-4; Chang 2008:32). Die Waarheidsen Versoeningskommissie het ' $n$ goeie begin gemaak om ruimte te skep vir die narratiewe van mense wat seergekry en seergemaak het sodat versoening en genesing kan plaasvind. Nou is die uitdaging om verder in Suid-Afrika die moontlikheid van narratiewe terapeutiese prosesse in gemeenskappe te ontgin.

NDP's is dikwels in 'n funksioneringstyl van oorlewing vasgevang. Mense wat so funksioneer, verloor dikwels uit die oog dat hulle steeds 'n sinvolle en konstruktiewe bydrae tot die samelewing kan lewer. In plaas van om hulle deur polarisasie te laat isoleer, kan gedeelde verhale en stemme wat gehoor word, bydra tot versoening met ander en heelwording in hulleself.

Die vertrekpunt van narratiewe terapie in die algemeen is om'n veilige ruimte te skep waar persone die vrymoedigheid kan hê om hulle unieke verhale te vertel. In die geval van NDP's is daar egter ' $n$ verswarende faktor wat hulle dikwels die vrymoedigheid ontneem om hulle verhale onbevange te vertel.

Baie voel skaam en skuldig oor apartheid en hulle betrokkenheid om dit in stand te hou, maar weet nie hoe om as individue restitusie te doen nie. Ander voel weer soos slagoffers van transformasie, verval in 'n 'laertrekmentaliteit' en isoleer hulleself. Pieter Bezuidenhout (2015:222-223) bespreek nie net hierdie verskynsel nie, maar ook geloofsorganisasies waaraan hulle behoort het se aandeel daarin. Hy beskryf dit as die 'SAW-dienspligveteranegenerasie' se ervaring van innerlike konflik oor die beskuldiging van apartheid en oor die kerk se aandeel daarin. Van die respondente in Bezuidenhout se 2015 studie, het $84 \%$ aangedui dat hulle ' $n$ behoefte het daaraan om sin te maak uit wat hulle beleef het en tot afsluiting te kom. Twee derdes van die respondente $(65 \%)$ het aangedui dat hulle ' $n$ behoefte het aan berading vanweë spesifieke ervarings of trauma wat hulle beleef het (Bezuidenhout 2015:214-215). Bezuidenhout se studie toon verder dat die oorgrote meerderheid (98.6\%) van die SAW-dienspligveteranegenerasie meen dat Afrikaanssprekende persone 'n rol speel in die welvaart, opbou en vooruitgang van Suid-Afrika. Daarvan beskou $90 \%$ hulleself as persone wat so 'n bydrae kan lewer en $93 \%$ besef dat hulle aan besluitneming en bestuur in die land behoort deel te neem. Die groot meerderheid van 93\% stem saam dat hulle vanweë hulle militêre en ander ervarings ' $n$ bydrae tot die nuwe Suid-Afrika kan lewer (Bezuidenhout 2015:244).

Die uitdaging vir die pastoraat is dus nie tot die afsluitingsproses ten opsigte van die verlede beperk nie, maar sluit ook die toerusting van NDP's in om effektief met die huidige stresvolle lewe in die veranderende Suid-Afrika te kan omgaan, asook om hulle te bemagtig om by projekte in die gemeenskap betrokke te raak. Praktiese teoloog, Daniël Louw (2005:124), bevestig dat die ideaal vir 'n samelewing sal wees om te 'fokus op die bemagtiging van mense; die uitbouing van ' $n$ menseregte kultuur en die beskerming van mense se unieke waarde teen alle vorme van uitbuiting'.

Die lewe as eksistensiële fenomeen ontvou in die basiese menslike behoefte aan intimiteit, erkenning en menswaardigheid. Om sinvol te kan lewe, vereis bemagtigingen ondersteuningstrukture wat aan hierdie basiese behoeftes kan voldoen (Louw 2012:11). Vanuit sy hermeneutiesesistemiese benadering tot die praktiese teologie en pastoraat verduidelik Louw (2005:17) die proses soos volg: 'Dit werk met perspektiewe op menswees en probeer om mense binne die gebeure van elke dag te verstaan.'

Hierdie artikel benut insigte uit die filosofiese beradingsmodel (philosophical counselling) van Daniël Louw (1999; 2005; 2011; 2012; 2015). Veral sy denke oor die leefruimte vir 'n menswaardige saambestaan en die hermeneutiek van suspisie ten opsigte van die menslike neiging om die ander as 'bedreigend' en 'vreemd' te kategoriseer (Louw 2005:124), is vir hierdie artikel van belang. Vir heling is 'posisieskuiwe' binne die samelewing soms onafwendbaar (kyk Louw 2005:124-132). In sy boek Netwerk van die menslike siel, wys Louw (2005:21-23) op die belangrikheid van 'posisionering' as 'kwalitatiewe inpassing binne 'n lewensgebeurlikheid, 'n spesifieke konteks/omgewing en in dinamies netwerk van verhoudinge.' Sisteemdenke behoort in samehang met hermeneutiese denke verstaan te word. Hy omskryf hermeneutiese denke soos volg (Louw 2005):

Hermeneutiese denke wil die verband tussen tekste en kontekste verstaan, interpreteer en vertolk met behulp van metafore (taal) en simbole (voorstellinge). In hermeneutiese denke gaan dit nie soseer oor substansie (syn) nie of verklaring (explanation) nie, maar om vertolking en om die ontdekking van samehange of netwerke waarbinne sin en betekenis tot uitdrukking gebring word. (bl. 24)

Die invloed van oorlogstrauma en die alledaagse ervaring van stres, woede, trauma, verlies, aanvaarding, heling, versoening en afsluiting, en hoe NDP's sedert 1990 daarmee omgegaan het, moet in die pastorale ondersteuning van veterane in ag geneem te word. Om die taak van versorging in die gemeenskap te kan volvoer, is dit nodig dat die pastoraat nie net aan die genesing van individue aandag gee nie, maar ook aan die genesing van paradigmas, perspektiewe, persepsies en idees (kyk Louw 2011:2). 
$\mathrm{NDP}^{\prime}$ s bevind hulle tans in die ouderdomskategorie van 40 jaar en ouer. Die grootste groep is in hulle middeljare. Die kompleksiteit van die situasie waarin hulle hulleself bevind, noodsaak die pastoraat om die kernbehoeftes aan ondersteuning te identifiseer en veterane die geleentheid te gee om hulle behoefte aan ondersteuning te benoem. Veterane behoort ook die vrymoedigheid te hê om deurlopend terugvoer oor die effektiwiteit van die begeleidingsproses te gee.

Ook Charles Gerkin (1997) se kontekstuele benadering tot pastorale sorg is vir hierdie artikel van belang omdat dit op 'n narratiewe, hermeneutiese verstaan van pastorale werk in 'n spesifieke konteks fokus. Volgens hierdie benadering word eers na verhale van persone geluister sodat hulle behoeftes binne hulle spesifieke sosiale omstandighede geïdentifiseer kan word. Na afloop van die pastorale berading word persone aangemoedig om konstruktief by sosiale en kulturele transformasie van die gemeenskap betrokke te raak.

Die interpretasiestruktuur van Gerkin het 'n dieper verstaan van die konteks waarin 'n holistiese pastorale begeleiding plaasvind, ten doel (kyk Figuur 1). Volgens Gerkin (1986:22) is die interpretasie van die omstandighede en die mate waarin individue in die situasie betrokke is, van primêre belang.

Heelwat NDP's ervaar die eksistensiële realiteite van hulle daaglikse lewe as 'n uitdaging. Met die term cura vitae bedoel Daniël Louw (2015:48) die genesing van lewe in alle dimensies van 'n persoon se eksistensie. 'n Persoon se spiritualiteit kan 'n direkte invloed hê op en betekenis gee aan die eksistensiële werklikhede van die alledaagse lewe. Louw se kosmiese benadering is op die eskatologiese daad van God in Christus ter wille van die hele skepping gebaseer. Volgens Kolossense 1:15-17 is Christus die beeld van die onsienlike God, die eersgeborene van die skepping en daarom behoort daar 'n inklusiewe en holistiese benadering tot genesing, genade en redding te wees: 'Alles is deur Hom en vir Hom geskep. Voor alles was Hy al daar en deur Hom bly alles in stand.' 'n Holistiese benadering het die heelheid van die lewe, van liggaam, siel en gees ten doel. Die dimensies wat in so 'n benadering tot die pastoraat ter sake is, sluit die volgende in: die affektiewe as die dimensie van gevoel en emosies; die kognitiewe as die dimensie van die menslike verstand en die vermoë tot rede, analitiese denke, rasionele insig en begrip; die konatiewe as die dimensie van die menslike wil, motivering en inspirasie; die liggaam en die stoflikheid, die fisiese, fisiologiese, biologiese, neurologiese en hormonale

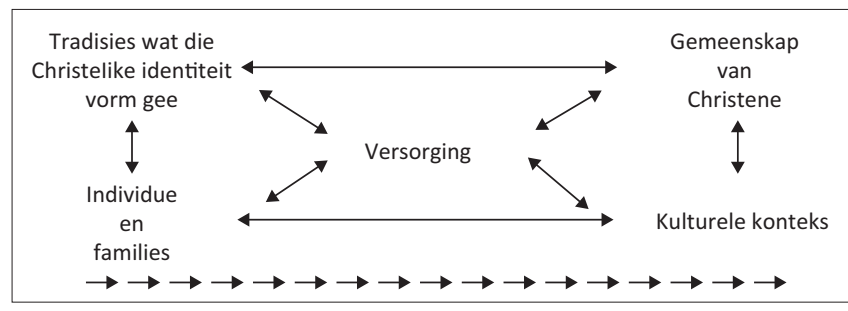

Bron: Gebaseer op Gerkin, C.V., 1997, An introduction to pastoral care, Abingdon, Nashville, TN FIGUUR 1: Die interpretasiestruktuur. aspekte van die menslike liggaam; die omgewing as die eksistensiële ruimte van verhoudingsnetwerke in kulturele, sosiale kontekste van gemeenskappe en ekosisteme; die spirituele as die dimensie van wysheid, kennis, gewete, gesonde verstand en insig, morele bewustheid, integriteit, konsistente en verantwoordelike denkpatrone en menslike toerekenbaarheid (Louw 2015:214).

Die spirituele dimensie sluit 'n persoon se wêreldbeskouing in. Dit is weer op spesifieke konstrukte en verskillende skemas van interpretasie gebaseer. Onderliggend hieraan is 'n persoon se geloofsoortuigings.

Praktiese teologie fokus op die spirituele dimensie van begeleiding en heling (Louw 2015:119), wat beteken dat pastorale sorg met verskillende geloofsisteme te doen kry. Die verskillende dimensies wat ter sake is in die pastorale begeleiding van gelowiges word in die spirituele sfeer geïntegreer. As deel van die holistiese benadering word ook aan die liggaam aandag gegee. Eksterne druk het 'n invloed op die brein en senuweestelsel. Sommige liggaamlike siektetoestande soos neurologiese siektes of breindisfunksie kan die gevolg daarvan wees. Christenberaders moet met die mediese professie saamwerk waar medikasie byvoorbeeld benodig word. Ook psigoloë en pastors kan saamwerk om 'n meer holistiese en dus meer effektiewe benadering te ontwikkel. 'n Lewensbeskouing wat op geloof berus en op 'n gesonde manier in die praktyk toegepas word en wat 'n balans tussen die natuurlike en geestelike aspekte van menswees bring, kan 'n gelowige persoon grootliks baat.

Samewerking met menswetenskappe ter wille van 'n effektiewe holistiese benadering, beteken nie dat die pastoraat die eie identiteit verloor nie. Gerkin (1997:121) beskryf dit soos volg: 'Pastoral care of a congregation of God's people involves the construction of a particular, context-relevant theological awareness on the part of both pastor and people.' Integrasie tussen teologie en die menswetenskappe vind binne die konteks plaas.

Anderson et al. (2000) bring die spiritualiteit van mense met hulle identiteit in verband. Die gelowige verkry 'n nuwe

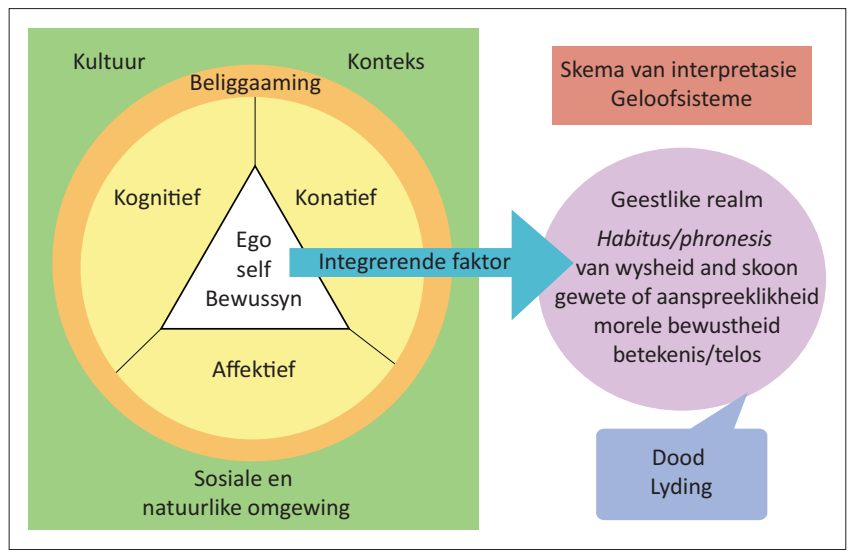

Bron: Gebaseer op Louw, D.J., 2005, Ratwerke van die menslike siel: Oor volwassenheid en lewensvaardighede, SUN Press, Stellenbosch

FIGUUR 2: Die antropologiese samestelling van die mens. 


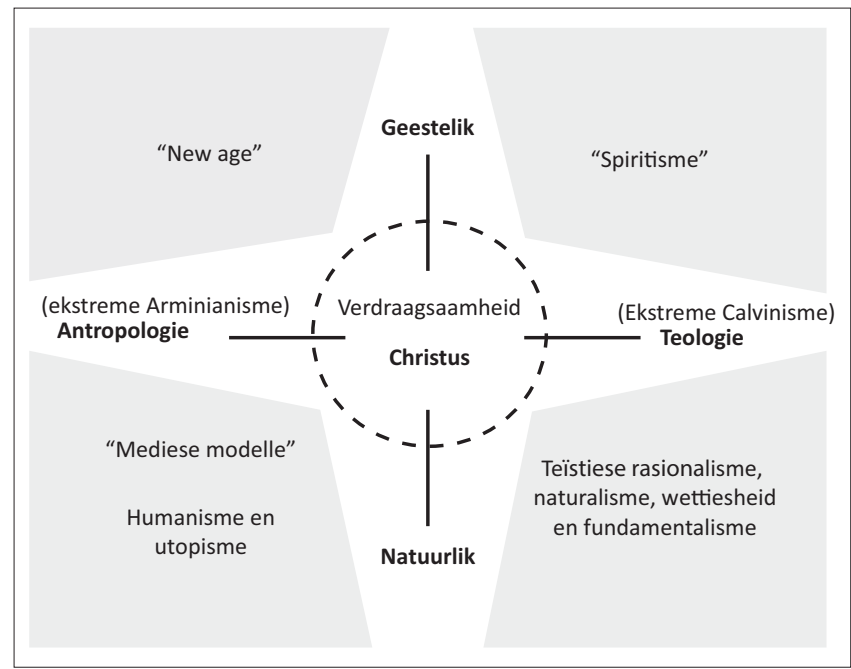

Bron: Anderson, N.T., Zuehlke, T.E. \& Zuehlke, J.S., 2000, Christ-centered therapy: The practical integration of theology and psychology, Zondervan, Grand Rapids, MI

FIGUUR 3: Balans in 'n bybelse wêreldbeskouing.

identiteit in Christus. Hulle onderskei tussen die identiteit van die persoon en die persoon se gedrag:

Who we are is not determined by what we do. What we do is determined by who we are and by the beliefs we have of ourselves and others ... As Christians we are not trying to become children of God (saints); we are children of God who are becoming like Jesus Christ. (Anderson et al. 2000:90)

Wat heiligmaking betref, onderskei hulle verder tussen positional sanctification (wat Christus reeds moontlik gemaak het) en progressive sanctification (om te word wat ons reeds in Christus is). Hoe identiteit ervaar en benoem word, byvoorbeeld of persone hulleself as " $n$ alkoholis' of " $n$ kind van God is wat sukkel met alkoholisme' beskou, het 'n bepalende uitwerking op die proses van heelwording. Dit is nie die mens se sukses wat reddende krag het nie, maar Christus wat kragtig werk in die persoon wat glo. Om net 'n persoon se gedrag te probeer verander, kan lei tot wettisisme en gedrewenheid. Volgens Anderson et al. (2000:92) kan reëls sonder 'n verhouding met God rebelsheid tot gevolg hê.

Daniel Louw (2011:3) se filosofiese berading is nie 'n vaardigheid of tegniek nie, maar ' $n$ proses van verstaan. Dit plaas die beperkte insig van mense in 'n groter prentjie wat tot nuwe insigte en 'n ander benadering tot die lewe kan bydra. Mense se 'teorieë' word op spesifieke idees gebou.

Hierdie idees beïnvloed hulle gedrag. Louw (2011:1) stel dit soos volg: 'Ideas shape and determine human self-understanding within existential realities.' Dit is waarom die versorging van mense en gemeenskappe erns behoort te maak met hulle paradigmas, perspektiewe, persepsies en idees. Indien die denkwêreld verwronge is en persone of gemeenskappe in die distorsie verhard, is diepgaande genesing, vrede en vreugde nie moontlik nie. Die vraag van filosofiese berading is nie: 'Hoe voel jy?' (die fokus op emosie) nie. In die benadering word eerder oor 'n persoon se betekenisraamwerk, motivering, waardestelsel en verwagtings uitgevra (kyk Louw 2011:4). In pastorale begeleiding is die doel om mense te fasiliteer om verantwoordelike keuses uit te oefen en om die gaping tussen die werklikheid en die ideaal te oorbrug. In die Afrikaanse kultuur leef daar byvoorbeeld konstrukte van manlikheid wat destruktief kan wees vir hulleself, hulle gesinne en die gemeenskap. Vanuit 'n filosofiese benadering kan hierdie konstrukte ondersoek en aanpassings aangebring word om verwronge persepsies reg te stel.

In verhale word metafore en simbole geïdentifiseer as deel van die interpretasieproses. Die relasies tussen hulle is ook van belang. Hoe daar met metafore en Godsbeelde omgegaan word, kan byvoorbeeld nuwe hoop en sin bied. Indien spesifieke interpretasieskemas raakgesien kan word, skep dit 'n noëtiese bewuswording. Dan kan gevestigde denkpatrone en die idees wat 'n persoon se optrede bepaal, bewustelik ondersoek word (kyk Louw 2011:5). In die pastorale ontmoeting gaan dit om die vertolking en verstaan van wie God vir mense in nood is. Die vraag is hoe hulle ' $n$ bepaalde Godsvoorstelling, -konsep of -beeld vertolk binne hulle konkrete omstandighede (Louw 1999:111-112). Louw (1999:115) beskryf die waarde hiervan soos volg: "n Metaforiese verstaan van God [bring] die aspekte van sensitiwiteit, medelye (patos), identifikasie (verwonding), insig en verstaan van paradokse (wyse dwaas), asook bystand en bemagtiging (paraklese) na vore.' Die interpretasieskemas van gelowiges toon hoe hulle God verstaan en hulle geloof in hulle alledaagse lewe toepas en uitleef. Dit is die spirituele dimensie van menswees. Pastorale assessering van Godsbeelde en metafore sal die toepaslikheid van die oortuigings in die persoon se alledaagse omstandighede evalueer.

Die soeke na sin en betekenis is dus ' $n$ hermeneutiese proses om die lewe en die sin van gebeurtenisse en ervarings soos lyding beter te verstaan. Volgens Louw is die soeke na sin en betekenis 'n posteriori ervaring. Dit gebeur wanneer basiese eksistensiële realiteite en behoeftes op so 'n wyse met spirituele verwagtings en oortuigings in verband gebring word dat hoop, geluk en dankbaarheid ervaar kan word. Sodra hierdie verband gelê word, kan die 'heling van die lewe' plaasvind (kyk Tabel 1).

Mense se eksistensiële behoeftes sluit in die behoefte aan intimiteit, vryheid, om iets nuuts te ervaar, 'n ondersteuningstruktuur, lewensvervulling, tevredenheid en geluk. Pastoraat vanuit 'n filosofiese beradingsperspektief help mense met teologiese konstrukte soos genade, vergifnis en versoening, hoop, gemeenskap (koinonia), diensbaarheid (diakonia) en dankbaarheid. Pastorale assessering evalueer die effektiwiteit van 'n persoon se lewensbeskouing (Louw 2011:6) vir die praktyk van hulle lewe en hulle welstand. Louw (2012:81) identifiseer twee eksistensiële aspekte van die 'om te wees'-funksie as, eerstens, die gehalte van die keuses wat gemaak word en die vlak waarop die keuses gemaak word; en tweedens, hoe die lewe geïnterpreteer word en die houding wat die persoon teenoor die lewe inneem. Dit het met 'n persoon se spesifieke paradigma, geloofsisteem en lewensfilosofie te doen.

In die proses van heling, verandering en groei, behoort die volle aandag nie op 'n individu se persoonlikheid te wees 
TABEL 1: Raamwerk vir sin en betekenis en die spirituele genesing van die lewe.

\begin{tabular}{|c|c|c|c|}
\hline $\begin{array}{l}\text { BEDREIGING } \\
\text { Eksistensiële probleme } \\
\text { LYDING }\end{array}$ & $\begin{array}{l}\text { KOMPULSIES } \\
\text { Oormatige soeke na sin en betekenis }\end{array}$ & $\begin{array}{l}\text { LEWENSBEHOEFTES } \\
\text { Wees behoeftes: die } \\
\text { moed om te wees }\end{array}$ & $\begin{array}{l}\text { GOD SE PRAKTYK } \\
\text { Christelike optrede }\end{array}$ \\
\hline $\begin{array}{l}\text { ANGS } \\
\text { Ervaring van verlies of verwerping }\end{array}$ & $\begin{array}{l}\text { EER EN HOOGMOED } \\
\text { Erkenning en agting }\end{array}$ & $\begin{array}{l}\text { INTIMITEIT } \\
\text { Bevestiging van waarde en identiteit }\end{array}$ & $\begin{array}{l}\text { GENADE } \\
\text { Onvoorwaardelike liefde } \\
\text { Beelde van God }\end{array}$ \\
\hline $\begin{array}{l}\text { SKULD } \\
\text { SKAAMTE }\end{array}$ & $\begin{array}{l}\text { PERFEKSIONISME } \\
\text { Vermy mislukking }\end{array}$ & $\begin{array}{l}\text { VRYHEID } \\
\text { Verlossing }\end{array}$ & VERGIFNIS VERSOENING \\
\hline $\begin{array}{l}\text { WANHOOP } \\
\text { TWYFEL }\end{array}$ & $\begin{array}{l}\text { OORBESKERMING } \\
\text { Soeke na absolute veiligheid }\end{array}$ & $\begin{array}{l}\text { VERWAGTING } \\
\text { Betekenis } \\
\text { Vertroue/geloof }\end{array}$ & $\begin{array}{l}\text { Eskatologiese verwagting van } \\
\text { HOOP }\end{array}$ \\
\hline HULPELOOSHEID KWESBAARHEID & $\begin{array}{l}\text { MAGSMISBRUIK } \\
\text { Manipulering van ander persone }\end{array}$ & ONDERSTEUNING-STRUKTUUR & $\begin{array}{l}\text { SAAMWEES } \\
\text { Koinonia } \\
\text { Diakonia }\end{array}$ \\
\hline $\begin{array}{l}\text { FRUSTRASIE, WOEDE } \\
\text { Teleurstelling en frustrasie: strukturele } \\
\text { aspekte soos armoede, werkloosheid, } \\
\text { geweld en misdaad }\end{array}$ & $\begin{array}{l}\text { GIERIGHEID } \\
\text { Om meer te besit en te meer te verkry }\end{array}$ & $\begin{array}{l}\text { LEWENSVERVULLING } \\
\text { RIGTING } \\
\text { TRANSFORMASIE } \\
\text { ROEPING }\end{array}$ & $\begin{array}{l}\text { DANKBAARHEID } \\
\text { VREUGDE } \\
\text { NAGMAAL } \\
\text { SAKRAMENTE } \\
\text { FEESVIERINGE }\end{array}$ \\
\hline
\end{tabular}

Bron: Louw, D.J., 2011, 'Philosophical counselling: Towards a “new approach” in pastoral care and counselling?', HTS Teologiese Studies/Theological Studies 67(2). https://doi.org/10.4102/hts.v67i2.900

nie, maar behoort ook aandag aan verhoudingsnetwerke en -prosesse gegee te word (Louw 2011:26). Effektiewe begeleiding vra dat ' $n$ veilige ruimte geskep word waarin persone hulle diepste seer en ontnugtering kan vertel. Deur middel van die vertel, kan nuwe moontlikhede ontdek word. Ruimte word vir ontmoeting, erkenning en aanvaarding geskep. Menswaardigheid kan ervaar word. Daarin kan sin en identiteit ontdek word (kyk Louw 2005:28). In die ruimte van verhoudings is die dinamika van interaksie soms spanningsvol. Louw $(2005 ; 2012)$ beklemtoon 'posisionering' as 'kwalitatiewe inpassing binne 'n lewensgebeurlikheid, ' $n$ spesifieke konteks/omgewing en in 'n dinamiese netwerk van verhoudinge' (Louw 2005:21-23). Posisionering te midde van moeilike lewensomstandighede kan konstruktiewe of destruktiewe gevolge vir mense inhou. Diegene wat aanspreeklikheid aanvaar en bereid is tot selfvergifnis en om hulle gesindheid of houding te verander, kan hulle op die pad na genesing en herstel in verhoudings bevind.

Vir heling is 'posisieskuiwe' in die samelewing soms onafwendbaar (kyk Louw 2005:28,124-132). In verhoudingsnetwerke identifiseer Louw (2005:35) vier posisies (houding of gesindheid). A en B dra dikwels by tot ' $n$ toepaslike houding, terwyl C en D die geneigdheid het om tot ontoepaslike houdings aanleiding te gee (kyk Figuur 4).

\section{- Posisie A: Akkommodasie}

In posisie A word verantwoordelikheid aanvaar. Die persoon onderskei tussen wat verander kan word en wat nie. Wat nie verander kan word nie, word aanvaar en geïntegreer. Dit word as 'n werklikheid gesien. Daarmee moet die persoon saamleef. Lewensdoelwitte word geformuleer om verandering aan te bring wat betref die self, die eie liggaam, ander mense, die werk, vermaak en ontspanning, of die spirituele dimensie.

Twee geloofsperspektiewe wat by akkommodasie ter sake is, is versoening en vergifnis. Vergifnis bring bevryding van skaamte en skuld mee. Dit bewerkstellig versoening en vrede. Vyandskap kan vir vriendskap verruil word.

\section{- Posisie B: Waardering}

Met waardering word 'n warm atmosfeer (veilige ruimte) van egtheid en vreugde wat met sensitiwiteit en empatie gepaard gaan, geskep. Empatie is die ingesteldheid om in die

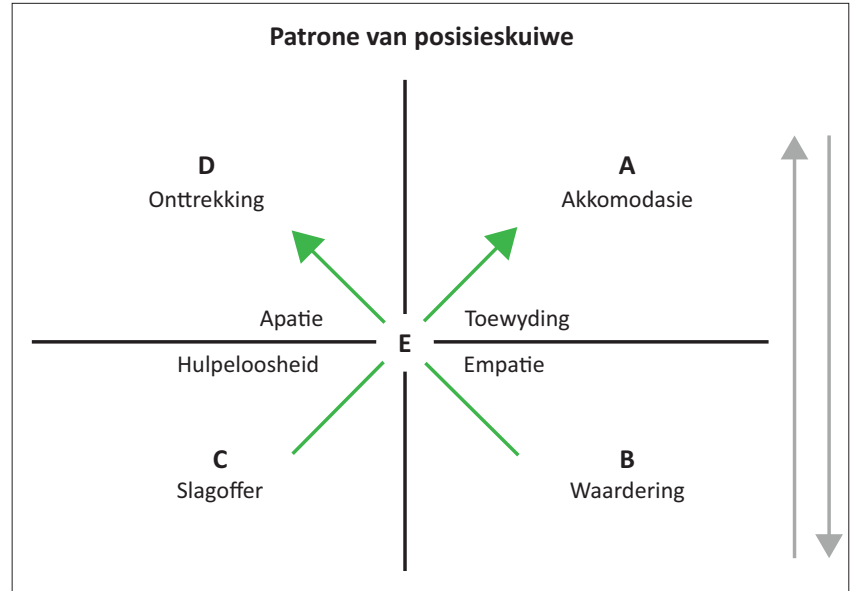

Bron: Louw, D.J., 2005, Ratwerke van die menslike siel: Oor volwassenheid en lewensvaardighede, SUN Press, Stellenbosch

FIGUUR 4: Patrone van posisieskuiwe. Die terapeutiese en helende moment binne die dinamiese netwerk van pole en posisies.

skoene van die ander probeer te staan, na hulle te luister en hulle te bemagtig om self nuwe moontlikhede te ondersoek. Sorgsaamheid en dankbaarheid vir 'n verandering in houding en gesindheid moet getoon word.

\section{- Posisie C: Frustrasie}

Die posisie van frustrasie lei tot 'n slagofferhouding. Negatiewe emosies van selfbejammering oorheers. Verhoudingsnetwerke kan as 'n gevangenis ervaar word. Persone voel hulpeloos en magteloos en kan na binne met passiewe aggressie of na buite met woede reageer. Langdurige neerslagtig kan tot depressie lei.

\section{- Posisie D: Onttrekking}

Onttrekking is om apaties op die appèl van 'n mens se verhoudingsnetwerk te reageer. Waar'n persoon onttrekking as 'onafhanklikheid' sien, beteken dat die eie belang sentraal staan, ongeag wat dit aan ander doen. Dit is'n selfgesentreerde lewenshouding. Dit kan aanduiding van 'n gevoel van meerderwaardigheid by die persoon wees.

\section{- Posisie E: Neutraliteit}

Neutraliteit kan beskryf word as die tussenin posisie. Dit het 'n konstruktiewe en destruktiewe kant. Dit kan op 'n gevoel 
van tevredenheid dui. Indien 'n persoon vanuit hierdie neutraliteit swyg eerder as om deel te neem aan en betrokke te raak by persone en die omgewing, kan die wyse waarop hulle ander ignoreer, verwarring en onsekerheid by ander veroorsaak. Uit 'n positiewe hoek gesien, kan 'n 'wag en kyk' houding soms 'n positiewe uitkoms hê. Soms is dit egter niks meer as gemaklike passiwiteit waarmee die persoon verantwoordelikheid en besluitneming ontduik nie.

Die volgende twee posisieskuiwe kan tot heling, verandering en groei lei. Die eerste is dié vanaf slagofferskap (C) na akkommodasie (A) en af na waardering (B). Die persoon neem verantwoordelikheid om weg te beweeg van $(C)$ en doelwitte in (A) te stel om met die nodige aanmoediging en ondersteuning na (B) te beweeg. In die veilige omgewing van (B) word die persoon aangemoedig om nuwe moontlikhede te laat realiseer. Die tweede is vanaf onttrekking (D) na waardering (B) en daarna na akkommodasie (A). Die persoon word begelei om uit isolasie na 'n veilige omgewing te beweeg (B) waar hy of sy erkenning en waardering ervaar. Daarna word beweeg na akkommodasie (A) waar doelwitformulering plaasvind.

Hierdie posisies is nie eties neutraal nie. Dit is eksistensiële houdingsgebeure met morele implikasies (kyk Louw 2005:28). Die spirituele dimensie van sulke posisieskuiwe kan op die terrein van motivering lê. Louw (2005:37-39) stel dit soos volg: 'Dit is die heil in Christus wat ons roep om via 'n gesindheidsverandering te skuif en sodoende heling en heelheid (wholeness) te bewerkstellig.' In die pastorale proses wat afsluiting by 'n dienspligveteraan begelei en hulle holisties ondersteun, sal die persoon self sy posisie bepaal en die motivering vind om die nodige aanpassings te maak vir heling. Dit is 'n proses wat lank kan duur en miskien nooit heeltemal afgesluit kan word nie.

\section{Bevindings}

Volledig afsluiting in die onafgehandelde transformasieproses in Suid Afrika is waarskynlik nie werklik moontlik nie. Afsluiting is ' $n$ proses sonder ' $n$ definitiewe einde. Nadat die aanvanklike groot werk op psigiese en spirituele vlak gedoen is, duur die genesings- en groeiproses voort. Vaardighede wat aangeleer is in die begeleidingsproses kan verder verfyn word. Pastorale ondersteuning aan veterane behoort nie net 'n saak tussen die veteraan en die berader te wees nie, maar behoort in plaaslike gemeenskappe geanker te wees. Die ondersteuningsbronne en-strukture wat in die gemeenskappe beskikbaar is, behoort ontgin en benut te word. 'n Kontekstuele benadering tot pastorale versorging bevorder 'n dieper verstaan van veterane in die konteks van die gemeenskappe waarin hulle hulleself bevind en die ondersteuning wat hulle nodig het. Pastorale begeleiding van NDP's het die sosiale sowel as persoonlike transformasie, asook 'n psigiese afsluitingsproses van mense wat op verskeie maniere in 'n oorlogsituasie verwond is, ten doel. Die ideale uitkoms van konstruktiewe betrokkenheid by hierdie groep mense is gesonder individue, families, gemeenskappe en 'n gesonder samelewing.

\section{Erkenning Mededingende belange}

Die outeurs verklaar dat hulle geen finansiële of persoonlike verbintenis het met enige party wat hulle nadelig kon beïnvloed in die skryf van hierdie artikel nie.

\section{Outeursbydrae}

Beide outeurs het was betrokke by die skryf van die artikel.

\section{Etiese oorwegings}

Hierdie artikel volg alle etiese standaarde vir navorsing sonder direkte kontak met mens of dier.

\section{Befondsing}

Hierdie navorsing het geen spesifieke toekenning ontvang van enige befondsingsagentskap in die openbare, kommersiële of nie-winsgewende sektore.

\section{Data beskikbaarheidsverklaring}

Data-deling is nie van toepassing op hierdie artikel nie, aangesien geen nuwe data in hierdie studie geskep of ontleed is nie.

\section{Vrywaring}

Die sienings en menings wat in hierdie artikel uitgedruk word, is dié van die outeur(s) en weerspieël nie noodwendig die amptelike beleid of posisie van enige geaffilieerde agentskap van die outeurs nie.

\section{Literatuurverwysings}

Anderson, N.T., Zuehlke, T.E. \& Zuehlke, J.S., 2000, Christ-centered therapy: The practical integration of theology and psychology, Zondervan, Grand Rapids, MI.

Anderson, N.T., 2010, The core of Christianity, Harvest House Publishers, Eugene OR.

Barman, R. \& Detweiler, M.B., 2014, 'Late onset stress symptomatology, subclinical PTSD or mixed etiologies in previously symptom free aging combat veterans', Journal of Traumatic Stress Disorders and Treatment 3(4), 2-7, https://doi. org/10.4172/2324-8947.1000132.

Bezuidenhout, P.H.S., 2015, 'Die dienspligveterane-SAW generasie en die soeke na heling, versoening en sosiale geregtigheid', PhD-proefskrif, Universiteit van die Vrystaat, Bloemfontein

Boshoff, W.S., 2011, 'Gemeentebou en die begeleiding van rouprosesse in ' $n$ konteks van omvattende verandering (stemme uit drie gemeentes van die NG Kerk se noordelike sinode)', PhD-proefskrif, Universiteit van Pretoria.

Brunsdon, A.R. \& Lotter, G.A., 2011, 'Auto-ethnography as self-help for ministers with ministry-fatigue: Exploratory remarks'. Verbum et Ecclesia 32(1), Art. \#465, 7 pages. doi:10.4102/ve.v32i1.465

Chang, H., 2008, Autoethnography as method: Developing autoethnographic inquiry, Left Coast Press, Walnut Creek, CA

David, R.E., 2017, 'Healing for the hurting: A holistic pastoral model for addressing Posttraumatic Stress Disorder in the Military', PhD thesis, Regent University, Virginia Beach, VA.

Davison, E.H., Pless, A.P., Gugliucci, M.R., King L.A., King D.W. Salgado, D.M., Spiro, A. \& Bachrach, P., 2006, 'Late-life emergence of early-life trauma: The phenomenon of late-onset stress symptomatology among aging combat veterans', Research on Aging 28(1), 84-114. https://doi.org/10.1177/0164027505281560

Doehring, C., 2018, 'Military moral injury: An evidence-based and intercultura approach to spiritual care', Pastoral Psychology 68, 15-30. https://doi. org/10.1007/s11089-018-0813-5

Dzinesa, G.A., 2008, 'The role of ex-combatants and veterans in violence in transitional societies', concept paper: Violence and Transition Project Roundtable, Centre for Study of Violence and Reconciliation, Johannesburg. 
Fuson, J.E., 2013, 'A pastoral counseling model for leading post-combat Christian soldiers experiencing spiritual injury to spiritual health through examining the biblical concepts of evil, pain, abandonment, and forgiveness', DMin thesis, Talbot biblical concepts of evil, pain, abandonment, and fo
School of Theology, Biola University, La Mirada, CA.

Ganzevoort, R.R., 2012, 'Narrative approaches', in B.J. Miller-McLemore (ed.), The Wiley-Blackwell Companion to Practical Theology, pp. 214-223, Wiley-Blackwell, Chichester.

Geldenhuys, J., 1993, Die wat wen: 'n Generaal se storie uit 'n era van oorlog en vrede, JL van Schaik, Pretoria.

Gerkin, C.V., 1986, Widening the horizons: Pastoral responses to a fragmented society, Westminster Press, Phildelphia.

Gerkin, C.V., 1997, An introduction to pastoral care, Abingdon, Nashville, TN.

Hamman, J.J., 2005, When steeples cry: Leading congregations through loss and change, The Pilgrim Press, New York.

Horesh, D., Solomon, Z., Zerach, G. \& Ein-Dor, T., 2011, 'Delayed-onset PTSD among war veterans: The role of life events throughout the life cycle', Social Psychiatry and Psychiatric Epidemiology 46(9), 863-870. https://doi.org/10.1007/s00127010-0255-6

Heinecken, L. \& Bwalya, H., 2013, 'Compensating military veterans in South Africa: What if we cannot pay the bill?', African Security Review 22, 30-46. https://doi.or $\mathrm{g} / 10.1080 / 10246029.2012 .752396$

Husted, K.N., 2008, 'Rural living combat veterans: An exploration on issues with pos traumatic stress disorder and reintegration post combat-returning to a small town', PhD thesis, Capella University, Minneapolis, MN.

Langer, R., 2011, 'Combat trauma, memory, and the World War II veteran', War, Literature \& the Arts: An International Journal of the Humanities 23(1) 50-58.

Louw, D.J., 1999, Pastoraat as vertolking en ontmoeting: Teologiese ontwerp vir 'n basisteorie, antropologie, metode en terapie, Lux Verbi, Kaapstad.
Louw, D.J., 2005, Ratwerke van die menslike siel: Oor volwassenheid en lewensvaardighede, SUN Press, Stellenbosch.

Louw, D.J., 2011, 'Philosophical counselling: Towards a "new approach" in pastora care and counselling?', HTS Teologiese Studies/Theological Studies 67(2). https:// doi.org/10.4102/hts.v67i2.900

Louw, D.J., 2012, Network of the human soul: On identity, dignity, maturity and life skills, SUN Press, Stellenbosch.

Louw, D.J., 2015, Wholeness in hope care: On nurturing the beauty of the human sou in spiritual healing, vol. 3, Lit Verlag GmbH \& Co, Zürich.

Malan, M., 2006, My lewe saam met die SA Weermag, Protea Boekhuis, Pretoria.

Moon, Z., 2016a, '(Re)turning warriors: A practical theology of military moral stress' Electronic Theses and Dissertations 1149, viewed 24 August 2018, from https:// digitalcommons.du.edu/etd/1149.

Moon, Z., 2016b, 'Pastoral care and counseling with military families', Journal of Pastoral Care \& Counseling 70(2), 128-135. https://doi.org/10.1177/1542305016633663

Port, C.L., Engdahl, B. \& Frazier, P., 2001, 'A longitudinal and retrospective study of PTSD among older prisoners of war', American Journal of Psychiatry 158(9), 1474-1479. https://doi.org/10.1176/appi.ajp.158.9.1474

Republic of South Africa, 2011, The Military Veterans Act, no. 18 of 2011, Government Printer, Pretoria.

Schoeman, R.P.G., 2019, 'Post-apartheid veterane se soeke na afsluiting: 'n Outoetnografiese pastorale benadering', PhD-proefskrif, Universiteit van Pretoria.

Snape, M. \& Henshaw, V., 2017, 'Flanders and Helmand: Chaplaincy, faith and religious change in the British Army, 1914-2014', Journal of Beliefs \& Values 38(2), 199-214. https://doi.org/10.1080/13617672.2017.1309509

Yan, G.W., 2016, 'The invisible wound: Moral injury and its impact on the health of operation enduring freedom/Operation Iraqi Freedom veterans', Military Medicine 181(5), 451-458. https://doi.org/10.7205/MILMED-D-15-00103 